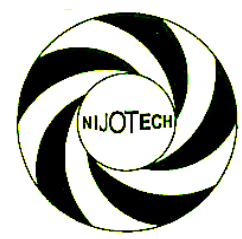

Nigerian Journal of Technology (NIJOTECH)

Vol. 39, No. 3, July 2020, pp. 680 - $\mathbf{6 8 6}$

Copyright@ Faculty of Engineering, University of Nigeria, Nsukka,

Print ISSN: 0331-8443, Electronic ISSN: 2467-8821 www.nijotech.com

http://dx.doi.org/10.4314/njt.v39i3.5

\title{
POZZOLANIC AND MECHANICAL PROPERTIES OF DATE PALM SEED ASH (DPSA) CONCRETE
}

\author{
A. S. J. Smith ${ }^{1}$, G. Xu 2, *, M. J. Garba ${ }^{3}$ and M. Y. Aliyu 4 \\ 1, 2, College of Civil Engr. And ARChitecture, ChinA Three Gorges University, YiCHANG, CHINA \\ 3, Centre for Satellite Technology Development, Obasanjo Space Centre, Garki, Abuja, Nigeria \\ 4, Department of Civil Engineering TeChnology, Kano State PolyteChniC, Kano State, NigeRIA \\ E-mail addresses: ${ }^{1}$ abutusmith@gmail.com, ${ }^{2}$ postxg@163.com, ${ }^{3}$ jamaamkr@gmail.com, \\ 4 aliyumustapha805@gmail.com
}

\begin{abstract}
This paper presents the findings of a research work conducted on how to improve the mechanical properties of concrete using Date Palm Seed Ash (DPSA) as partial replacement of cement. The DPSA used was obtained by controlled burning of date palm seed in a kiln at a maximum temperature of $630^{\circ} \mathrm{C}$ for eight hours and air cooled afterwards. The ash obtained was sieved through $75 \mu \mathrm{m}$ sieve and its oxide composition analysed using $X$-ray fluorescence (XRF) procedures. DoE method of mix design was used to produce concrete ingredients for grade $30 \mathrm{~N} / \mathrm{mm}^{2}$ giving a water-cement ratio of 0.53 . The effect of partial replacement of cement with DPSA on cement paste and concrete using 0, 2.5, 5, 7.5, 10, 15 and 20\% DPSA was investigated through consistency and setting times tests, workability test, compressive strength test (at 7, 21, 28 and 56 days curing duration), pozzolanic activity index evaluation and water absorption test. Results show that DPSA has high silicon dioxide (45.50\%), aluminum oxide (20.75\%) and Iron oxide (7.25\%). Findings indicate that the consistency and setting times of cement-DPSA paste increased with increase in the replacement of cement with DPSA. The workability of DPSA concrete decreased with increase in cement replacement. Compressive strength test results show that cement can be replaced with DPSA up to $10 \%$ as the compressive strength at $10 \%$ replacement is $31.5 \mathrm{~N} / \mathrm{mm}^{2}$ as against the $31 \mathrm{~N} / \mathrm{mm}^{2}$ of the normal concrete, at 56 days. The pozzolanic activity index result also show that DPSA concrete meets up the minimum requirement of $75 \%$ specified by ASTM C618-15. Also, the water absorption capacity of DPSA concrete at the highest replacement (20\%) is $11 \%$ less than that at 0\%.
\end{abstract}

Keywords: Cement, Compressive strength, Concrete, Date palm seed ash, Partial replacement, Pozzolana

\section{INTRODUCTION}

Concrete is made by mixing the right proportion of cement, fine aggregate, coarse aggregate, water and sometimes admixtures added to modify certain of its properties both in the fresh and hardened forms. Concrete is of three types namely: heavy weight, normal weight and light weight concrete. Concrete is a reliable material that is applied in many kinds of construction developments given its many desirable properties. However, report indicates that concrete made with conventional Portland cement suffers several problems like brittleness, low tensile strength, as well as susceptibility to acid and sulphate attacks
[1]. In order to solve some if not all of these problems, the construction industry is changing drastically with changes in conventional building materials such as bricks and stones to newer materials like fibrereinforced plastics, aluminium, glass and steel. In fact, the list of new materials in the construction industry is almost in-exhaustive which is good for the economy of the building and construction industry [2].

Nigeria's building and construction industry, like many other developing countries, is exploring and combining materials within its vicinity so as to meet the ever increasing demand of shelter for man. The choice and sustainability of a particular material depends largely

* Corresponding author, tel: +861 - 599 - 760 - 3205 
on its availability, nature of projects, durability, individual preference and economic considerations. However, efforts made to provide materials which are comparable to the strength of cement composites have not significantly reduced the cost of construction [3]. And since the demand in the concrete manufacturing is increasing day by day, the utilization of river sand as fine aggregate and the use of natural stones as coarse aggregate lead to exploitation of natural resources, resulting into ecological imbalance of the environment, lowering of water table, sinking of the bridge piers as a common threat. Great efforts have been made by researchers on studying the suitability of materials like palm kernel shells, incinerated ash, crushed glass, periwinkle shells for concrete production [4]. Just as new materials are being researched for replacement of conventional fine and coarse aggregates, so also new materials are being researched to be used in partial replacement of cement [5]. In recent years, many researchers; [6 8] have established that the use of supplementary cementitious materials (SCMs) can, not only improve the various properties of concrete (both in its fresh and hardened states) but also can contribute to economy in construction costs [9]. These cementitious materials are known as "Pozzolanas."

In North America, natural pozzolanas have been in use since the early $20^{\text {th }}$ century for public works projects, such as dams, to control temperature rise in mass concrete and provide cementitious material [10]. In addition to controlling heat rise, [10] also stated that natural pozzolanas were used to improve resistance to sulfate attack and were among the first materials to be found to mitigate alkali-silica reaction. The most common natural pozzolanas used today are processed materials, which are heat treated in a kiln and then ground to a fine powder; they include calcined clay, calcined shale, fly ash (FA), blast furnace slag (BFS), silica fume, metakaolin (MK), rice husk ash (RHA), hypo sludge [11].

In contribution to the ongoing research in finding suitable materials to replace conventional construction materials, the use of Date Palm Seed (DPS) as coarse aggregate has been studied by [12]. Date Palm Seed is obtained from date palm (Phoenix dactylifera), tree of the palm family (Arecaceae or Palmae) which can be found in Canary Islands, Northern and Western Africa, the Middle East, Pakistan, India, and the U.S. State of California. Date is highly cultivated for animals and human consumptions. As stated by [12], after consumption, the seeds (DPS) served as nothing but contribute to wastes and littered the environment. The aim of this study is to investigate the potentials of using Date palm seed ash as cement replacement material in concrete production with the objectives of determining the pozzolanic properties of DPSA, as well as determining the effect of DPSA on: consistency and setting times of cement paste, concrete workability, compressive strength of concrete and water absorption capacity of concrete.

\section{MATERIALS AND METHODS}

\subsection{Materials}

\subsubsection{Date Palm Seed Ash (DPSA)}

Date Palm Seed is an agricultural produce from date palm (Phoenix dactylifera), tree of the palm family (Arecaceae or Palmae) which can be found in Canary Islands, Northern and Western Africa, the Middle East, Pakistan, India, and the U.S. State of California. Date is highly cultivated for animals and human consumptions. After consumption, the seeds (DPS) served as nothing but contribute to wastes and littered the environment [12]. The date palm seed was obtained from date palm sellers in Yankura and Wambe markets of Kano state, Nigeria. The seeds were burnt in a kiln in two stages in order to obtain the amorphous form of the ash: Firstly, the DPS was burnt for a duration of eight hours at a temperature of about $590^{\circ} \mathrm{C}$. Secondly, after allowing it to cool for two days, it was further burnt for three hours at a temperature of $630^{\circ} \mathrm{C}$ and was again allowed to cool for another three days. The ash obtained from the burning was then sieved through $75 \mu \mathrm{m}$ sieve before it was used for concrete production.

\subsubsection{Cement}

The cement used was Ordinary Portland cement manufactured by Dangote cement plc, it is available in $50 \mathrm{~kg}$ bag in Nigeria and was observed to conform to [13].

\subsubsection{Fine Aggregates}

The fine aggregate used was clean river sand from Chalawa river in Kumbotso Local government area of Kano state, Nigeria. The fine aggregate conformed to [14].

\subsubsection{Coarse Aggregates}

The coarse aggregate used was clean, crushed granite obtained from Rano quarry site in Kano state, Nigeria and it conformed to [14]. 


\subsubsection{Water}

The water used was tested and conformed to [15]. It was portable and was obtained from the water supplied by Bayero University Kano to Civil Engineering department laboratory.

\subsection{Methods}

\subsubsection{Specific Gravity}

This test was conducted on cement, DPSA, sand and crushed granite in accordance with [16]. The specific gravity of sand, granite, cement and Date palm seed ash is shown in Table 2.

\subsubsection{Concrete Mix Design}

Department of Environment (DoE) method of mix design [17] was used to determine the quantity of the various concrete ingredients (cement, sand, granite and water) required to produce a concrete grade of $30 \mathrm{~N} / \mathrm{mm}^{2}$ for this research work, and this method gave a mix design of 1.0:1.850:2.625 (cement: fine aggregate: coarse aggregate) and water-cement ratio of 0.53 . Medium size slump of $30-60 \mathrm{~mm}$ and maximum aggregate size of $20 \mathrm{~mm}$ were used for this design. The concrete mix proportion is shown in Table 1.

\subsubsection{Chemical Composition of DPSA:}

Oxide composition of cement and DPSA was conducted based on [18] at Centre for Energy Research and Training (CERT) Samaru Zaria, Kaduna State. Mineral oxide composition of cement and DPSA were obtained by X-Ray fluorescence (XRF) analysis. Results from this analysis is presented in Table 3.

\subsubsection{Consistency and Setting Times of Cement- DPSA Paste:}

Consistency and setting times of cement-DPSA paste was carried out using 0, 2.5, 5, 7.5, 10, 15 and 20\% DPSA to replace cement in accordance with [19]. The result is shown in Figure 1 and 2.

\subsubsection{Slump of DPSA Concrete:}

The workability of fresh DPSA concrete was determined based on [20] using the designed mix stated in section 2.2.2 and the result is shown in Figure 3.

\subsubsection{Compressive Strength of DPSA Concrete} Compressive strength of DPSA concrete was carried out after curing for 7, 21, 28 and 56 days based on [21]. $75 \mu \mathrm{m}$ fineness of DPSA was used to replace cement at $0,2.5,5,7.5,10,15$, and $20 \%$. Cube mould of sizes $100 \mathrm{~mm} \times 100 \mathrm{~mm} \times 100 \mathrm{~mm}$ was used to cast a total of 84 cubes for compressive strength test. The compressive strength behavior is shown in Figure 4.

\subsubsection{Pozzolanic Activity Index (PAI) of DPSA Concrete}

Pozzolanic activity index (PAI) of DPSA concrete was evaluated in accordance with [18] as specified by [22] that; the strength activity index of a pozzolana must meet the requirement of $75 \%$ of the control strength at 7 days or 28 days. The results are shown in Table 4.

\subsubsection{Water Absorption of DPSA Concrete}

The water absorption capacity of DPSA concrete was determined based on [23]. 75 $\mu \mathrm{m}$ fineness of DPSA was used to replace cement at $0,2.5,5,7.5,10,15$, and $20 \%$. Cube mould of sizes $100 \mathrm{~mm} \times 100 \mathrm{~mm} \times$ $100 \mathrm{~mm}$ was used to cast a total of 21 cubes for water absorption test and the behavior is shown in Figure 5.

\section{RESULTS AND DISCUSSIONS}

\subsection{Specific Gravity}

The Specific gravity of cement, date palm seed ash (DPSA), sand and granite is shown in Table 2.

Table 1: Concrete Quantities at various Replacement of DPSA

\begin{tabular}{cccccc}
\hline $\begin{array}{c}\text { DPSA } \\
\begin{array}{c}\text { Content } \\
(\%)\end{array}\end{array}$ & $\begin{array}{c}\text { Cement } \\
\left(\mathrm{kg} / \mathrm{m}^{3}\right)\end{array}$ & $\begin{array}{c}\text { DPSA } \\
\left(\mathrm{kg} / \mathrm{m}^{3}\right)\end{array}$ & $\begin{array}{c}\text { Sand } \\
\left(\mathrm{kg} / \mathrm{m}^{3}\right)\end{array}$ & $\begin{array}{c}\text { Granite } \\
\left(\mathrm{kg} / \mathrm{m}^{3}\right)\end{array}$ & $\begin{array}{c}\text { Water } \\
\left(\mathrm{kg} / \mathrm{m}^{3}\right)\end{array}$ \\
\hline 0.0 & 400.0 & 0.0 & 740.0 & 1050.0 & 210.0 \\
2.5 & 390.0 & 10.0 & 740.0 & 1050.0 & 210.0 \\
5.0 & 380.0 & 20.0 & 740.0 & 1050.0 & 210.0 \\
7.5 & 370 & 30.0 & 740.0 & 1050.0 & 210.0 \\
10 & 360.0 & 40.0 & 740.0 & 1050.0 & 210.0 \\
15 & 340.0 & 60.0 & 740.0 & 1050.0 & 210.0 \\
20 & 320.0 & 80.0 & 740.0 & 1050.0 & 210.0 \\
\hline
\end{tabular}

Table 2: Specific Gravity of Concrete Materials

\begin{tabular}{cc}
\hline Sample & Specific Gravity \\
\hline Cement & 3.15 \\
DPSA & 1.44 \\
Sand & 2.68 \\
Granite & 2.65 \\
\hline
\end{tabular}

\subsection{Chemical Composition of DPSA}

The result of chemical analysis of DPSA is shown in Table 3. The total percentage composition of Iron oxide $\left(\mathrm{Fe}_{2} \mathrm{O}_{3}=7.25 \%\right)$, Silicon dioxide $\left(\mathrm{SiO}_{2}=45.50 \%\right)$ and Aluminium oxide $\left(\mathrm{Al}_{2} \mathrm{O}_{3}=20.75 \%\right)$ summed up to $73.50 \%$, which satisfies the $70 \%$ minimum requirement specified by [18], and hence it is a good 
pozzolana. The analysis also showed that DPSA has a substantial amount of Calcium oxide $(\mathrm{CaO}=9.82 \%)$ which makes the ash to be self-cementitious. It also has $9.07 \%$ of potassium oxide $\left(\mathrm{K}_{2} \mathrm{O}\right)$ and $3.0 \%$ Sodium oxide $\left(\mathrm{Na}_{2} \mathrm{O}\right)$ which may inhibit the formation of Calcium trisilicates in concrete and hence affect strength at early curing age as reported by [24]. The alkali content in DPSA also exceed the limit of alkali known as equivalent sodium oxide content of cement and expressed as $\left(\mathrm{Na}_{2} \mathrm{O}\right)=\mathrm{Na}_{2} \mathrm{O}+0.658 \mathrm{~K}_{2} \mathrm{O}$ allowed in cement [25], which may affect the concrete durability in terms of drying shrinkage [26], as it makes the microstructure of Calcium trisilicates hydrate to become coarser and heterogeneous in alkali solutions according to [27], in agreement to [28] report that high-alkali cement pastes have a less dense microstructure compared to low-alkali cement pastes. Meanwhile, pozzolana with high alkali content can be used in concrete to delay the final setting time of concrete. The combined content of Silicon dioxide, Iron oxide and Aluminium oxide is responsible for the pozzolanic activity [29] of DPSA. In addition, DPSA also possesses cementitious property that most pozzolana lack due to the substantial quantity of Calcium oxide in its oxide composition. This makes DPSA a good replacement material of cement for concrete production.

\subsection{Consistency and Setting Times of Cement- DPSA Paste}

The consistency and setting times of cement-DPSA paste for cement replacement with DPSA as shown in Figures 1 increased with increase in DPSA content.

The consistency increased because of particle interference effect, and so a large amount of water is needed to properly wet higher percentage of DPSA in the mix to produce cement gel as the cement is more soluble than the DPSA, and this led to the increase in the consistency of the DPSA concrete as explained by [30]. The increase in setting times may be due to the high content of $\mathrm{K}_{2} \mathrm{O}$ in the ash which may react with water to produce caustic potassium hydroxide that absorbs the water available for hydration of cement, as reported by [31]. Also, the setting times for all percentage replacement of cement with DPSA are within [32] specification for Ordinary Portland Cement, which is a minimum of 45 minutes for initial setting time and a maximum of 375 minutes for final setting time. The increase in setting times of DPSA concrete means that DPSA can be used as a set retarder in concrete to be transported over a long distance.

\subsection{Slump of DPSA Concrete}

The slump of DPSA concrete as shown in Figure 2 decreased with increased content of DPSA and this may be due to particle interference effects, in that the loss on ignition of DPSA $(1.72 \%)$ is higher than that of the cement (1.3\%) used as explained by [5]. The result also showed that all the slumps except that for $20 \%$ DPSA mix is within the range of medium workability (35mm-75mm) as specified in [20].

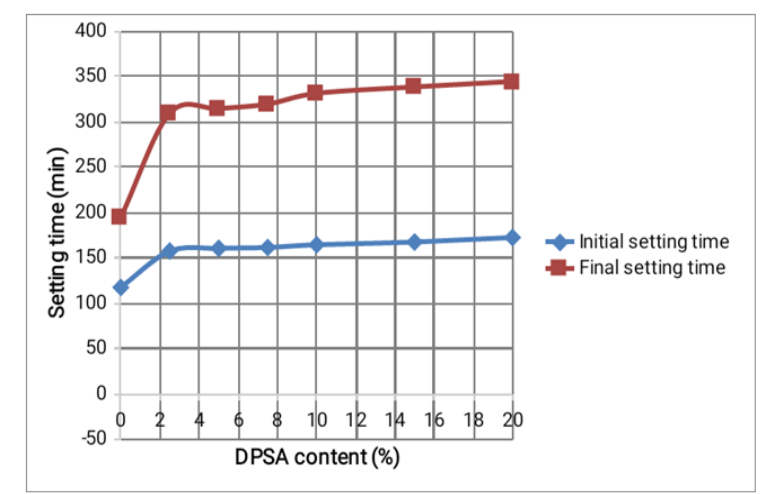

Figure 1: Setting times of cement-DPSA paste for cement replacement

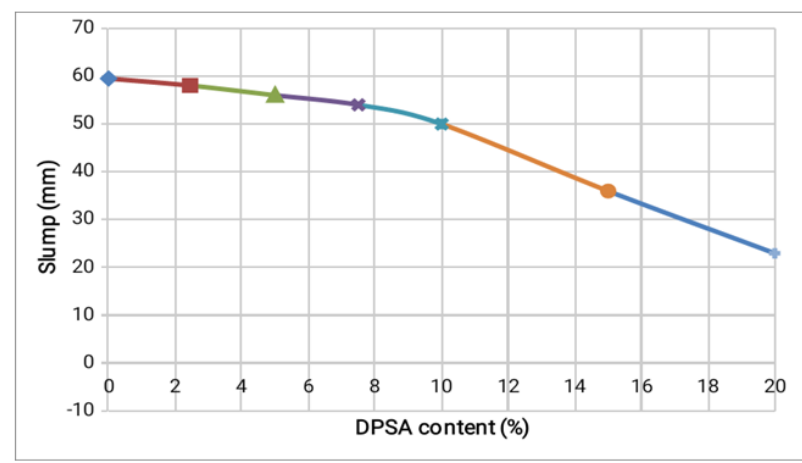

Figure 2: Slump of DPSA concrete

This makes DPSA concrete up to $10 \%$ replacement of cement good for lightly reinforced concrete section without vibrations and heavily reinforced sections with vibrations [33]. DPSA concrete higher than 10\% replacement of cement with low workability can also be used for mass concrete projects as explained by Jackson and cited by [34].

\subsection{Compressive Strength of DPSA Concrete}

Results of the compressive strength of DPSA concrete as shown in Figure 3 show that the compressive strength of DPSA concrete up to $10 \%$ replacement is higher than control and design strength at 56 days with $2.5 \%$ replacement giving the optimum strength of $33 \mathrm{~N} / \mathrm{mm}^{2}$. The $2.5 \%$ optimum strength may be due to the hydration of cement and DPSA. The 10\% 
replacement strength could be due to the DPSA behaving as a filler that deccelerates cement hydration. This decceleration of the hydration process generates more calcium hydroxide at later curing ages to react with the active silica and aluminate phases of the DPSA to produce secondary calcium aluminosilicate hydrates, enhancing strength performance [35]. Further increase in DPSA content showed a decrease in compressive strength when compared with the normal concrete. The reduction in compressive strength with $15 \%$ and $20 \%$ replacement of cement with DPSA may be due to the saturation of the cement mix with $\mathrm{K}_{2} \mathrm{O}$ in DPSA which forms composite that inhibits the formation of calcium silicate hydrates from cement hydration as reported by [24]. DPSA can be used up to $10 \%$ to replace cement for concrete production since the results showed that DPSA concrete tends to gain more strength over a longer period of time beyond 28 days curing age in agreement to [36].

\subsection{Pozzolanic Activity Index (PAI) of DPSA Concrete}

Table 4 shows the results of pozzolanic activity index of DPSA concrete. It is seen that at both 7 and 28 days curing age, the PAI for $20 \%$ DPSA meet the minimum requirement specified by [22] that the strength activity index of a pozzolana must meet the requirement of $75 \%$ of the control strength at 7 and 28 days. This indicates that DPSA is a good pozzolana and can be used to replace cement for concrete production.

\subsection{Water Absorption of DPSA Concrete}

Water absorption of concrete containing DPSA as shown in Figure 4 reviews that the water absorption decreased with increase in the quantity of DPSA as compared with the normal concrete.

This is because the paste formation from cementDPSA reaction coats the aggregates and larger micro voids better than that resulting from cement, since
[37] reported that water absorption mechanism depends on factors like paste pores, capillarity, surface energy, surface tension and concrete sorptivity. The figure also indicates that the water absorption for each percentage replacement of cement with DPSA is less than that for normal concrete. Meanwhile, the water absorption for all the mixes are well below the maximum of $10 \%$ stated by [33]. This low water absorption capacity of DPSA concrete makes it a more suitable concrete than normal concrete for construction works in a waterlogged environment.

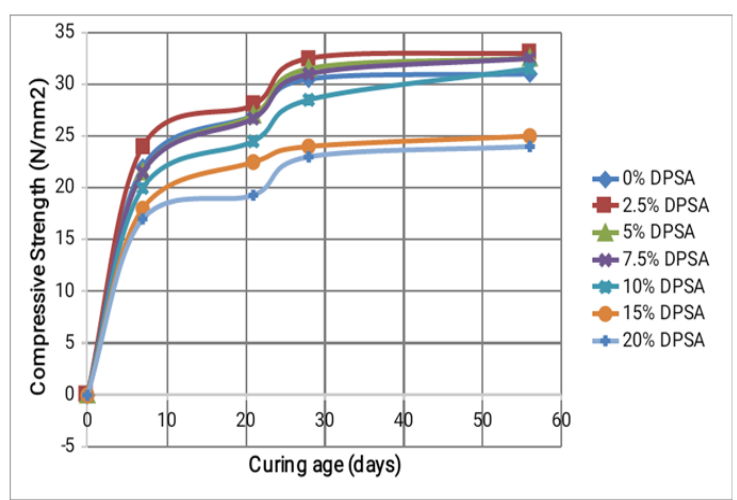

Figure 3: Compressive strength of DPSA concrete

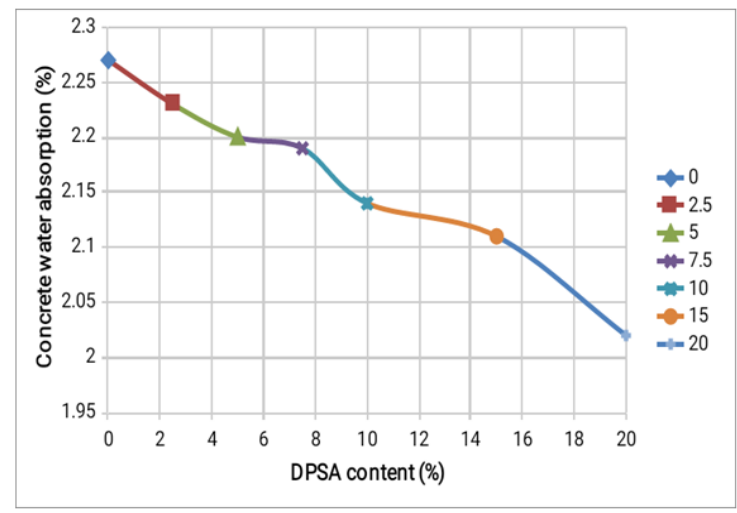

Figure. 4: Water absorption of DPSA concrete

Table 3: Oxide Composition of Date Palm Seed Ash (DPSA) and Ordinary Portland Cement used

\begin{tabular}{ccccccccccc}
\hline Oxide & $\mathrm{SiO}_{2}$ & $\mathrm{Fe}_{2} \mathrm{O}_{3}$ & $\mathrm{Al}_{2} \mathrm{O}_{3}$ & $\mathrm{P}_{2} \mathrm{O}_{5}$ & $\mathrm{CaO}$ & $\mathrm{K}_{2} \mathrm{O}$ & $\mathrm{Cl}$ & $\mathrm{SO}_{3}$ & $\mathrm{Na}_{2} \mathrm{O}$ & $\mathrm{ZnO}$ \\
\hline DPSA (\%) & 45.5 & 7.25 & 20.75 & 0.50 & 9.82 & 9.07 & 0.45 & 0.12 & 3.00 & 0.31 \\
OPC (\%) & 20.99 & 9.72 & 10.30 & - & 55.00 & 0.72 & - & 0.40 & 0.33 & - \\
Oxide & $\mathrm{MgO}$ & $\mathrm{BaO}$ & $\mathrm{MnO}$ & $\mathrm{PbO}$ & $\mathrm{ZrO}_{2}$ & $\mathrm{As}_{2} \mathrm{O}_{3}$ & $\mathrm{LOI}$ & & & \\
DPSA (\%) & 0.52 & 0.05 & 0.32 & 0.02 & 0.05 & 0.55 & 1.72 & & & \\
OPC (\%) & 0.44 & - & 0.80 & - & - & - & 1.30 & & & \\
\hline
\end{tabular}


Table 4: Pozzolanic Activity Index of DPSA Concrete

\begin{tabular}{ccccc}
\hline \multirow{2}{*}{$\begin{array}{c}\text { DPSA } \\
\text { content } \\
(\%)\end{array}$} & \multicolumn{2}{c}{$\begin{array}{c}\text { Compressive strength } \\
\left(\mathrm{N} / \mathrm{mm}^{2}\right)\end{array}$} & \multicolumn{2}{c}{ PAl $(\%)$} \\
\cline { 2 - 5 } & 7 days & 28 days & 7 days & 28 days \\
\hline 0 & 22.0 & 30.5 & --- & --- \\
20 & 17.0 & 23.0 & 77.3 & 75.4 \\
\hline
\end{tabular}

\section{CONCLUSION}

The results of pozzolanic property and evaluation (oxide composition and pozzolanic activity index) of DPSA concrete as reported in this research work have shown that it is a good pozzolana. Concrete made using DPSA to partially replace cement can be used for projects involving long hauling distances due to its increased final setting time. DPSA can be used up to $10 \%$ to replace cement for concrete production in order to improve its compressive strength. The decreased water absorption capacity of DPSA concrete with increased DPSA content is a sign that DPSA concrete will be more durable than normal concrete in an environment where the concrete is exposed to water in form of a solution

\section{RECOMMENDATION}

It is recommended that further tests be conducted to determine the durability potentials of DPSA concrete. Test should also be conducted to determine the effects of DPSA on the mechanical properties of concrete for longer curing duration beyond 56 days.

\section{REFERENCES}

[1] Hidayah, N. B. R. "Effect of Steel Slag and Steel Sludge on Concrete Properties" http://eprints. utm.my/id/eprint/48936/25/NurulHi dayahRoslanMFKA2014.pdf, Accessed on October 6, 2016.

[2] Olanipekun, E. A., Ata, O. and Olusola, K. O. "A Comparative Study of Concrete Properties Using Coconut Shells and Palm kernel Shells as Aggregate", Journal of Building and Environment, Vol. 3, Number 1, 2006, pp 279-301.

[3] Nuhu-Koko, M. K. "The use of Palm Kernel Shells as Aggregates for Concrete", Paper presented at The $21^{\text {st }}$ Annual Conference of Materials Testing, Control and Research, FMW Lagos, Nigeria, 1990, pp20.

[4] Saand, A., Bangwar, D. K. and Keiro, M. A. "Development of Polymer Modified Rice Husk Ash Concrete", Advanced Materials Research Vol. 11, Number 29, 2015, pp 500-507.
[5] Ramezanianpour A. A. "Cement Replacement Materials", Springer Geochemistry/Mineralogy, DOI: 10.1007/978-3-642-36721-2 2, Accessed on September 27, 2017.

[6] Mara, W. and Ogork, E. N. "Assessment of Groundnut Shell Ash as Admixture in Cement Paste and Concrete", International Journal of Innovative Science and Technology, Vol. 2, Number 2, 2015, pp 77-86.

[7] Adewuyi, A. P. and Ola, B. F. "Application of Waterworks Sludge as Partial Replacement for Cement in Concrete Production", Science Focus Journal, Vol. 10, Number 1, 2005, pp 123-130.

[8] Elinwa, A. U. and Awari, A. "Groundnut Husk Ash Concrete", Nigerian Journal of Engineering Management, Vol. 2, Number 1, 2001, pp 8-15.

[9] Elinwa, A. U., Ejeh, S. P. and Akpabio, I. O. "Using Metakaolin to Improve Sawdust Ash Concrete", Concrete International Journal, vol. 27, Number 11, 2005, pp 49-52.

[10] Kourd, A. and Adel, H. "ECIV 3341: Cement and Concrete Technology Lecture Notes", http://site. iugaza.edu.ps/izreid/files/2010/03/ce ment-concrete-technology.pdf, Accessed on June 15, 2017.

[11] Hidaya, N. B. R., Mohammad, I., Zaiton, A., Seyedmojtaba, G. and Bala, M. "Performance of Steel Slag and Steel Sludge in Concrete", Construction and Building Materials, Vol. 104, 2016, pp 16-24.

[12] Aka, A., Muhammad H. N., Ephraim T. K. and Idris A. W. "Exploratory Study of Date Seed as Coarse Aggregate in Concrete Production", Civil and Environmental Research, Vol. 3, Number 1, 2013, pp 85-92.

[13] British Standard Code of Practice. "BS EN 196-1: Method of Testing Cement-Determination of Strength", British Standard Institution, London, 2016.

[14] British Standard Code of Practice. "BS 882: Specification for Aggregates from Natural Sources for Concrete", British Standard Institution, London, 1992.

[15] British Standard Code of Practice. "BS 3148: Methods of test for water for making concrete", British Standard Institution, London, 1980.

[16] British Standard Code of Practice. "BS8500: Method for Determination of Specific Gravity of Concrete Ingredients", British Standard Institution, London, 2000. 
[17] Bala M. "Design of Concrete Mix Using Department of Environment Method from CIV 8321: Advanced Construction Materials and Technology", Accessed on January 2, 2017.

[18] American Society for Testing and Materials. "Standard test methods for sampling and testing fly ash or natural pozzolans for use in Portland cement concrete", ASTM C311/C311M-16, Annual Book of ASTM, ASTM International, West Conshohocken, PA, 2016.

[19] British Standard Code of Practice. "BS EN 196-3: Method of Testing Cement-Determination of Setting Time and Soundness", British Standard Institution, London , 1995.

[20] British Standard Code of Practice. "BS EN 123502: Method for Determination of Slump in Concrete", British Standard Institution, London, 2009.

[21] British Standard Code of Practice. "BS EN 123903: Method for Determination of Compressive Strength of Concrete', British Standard Institution, London, 2009.

[22] American Society for Testing and Materials. "Standard specification for coal fly ash and raw or calcined natural pozzolan for use in concrete", ASTM C618-15, Annual Book of ASTM, ASTM International, West Conshohocken, PA, 2015.

[23] British Standard Code of Practice. "BS EN 123906: Method for Determination of Water Absorption of Concrete", British Standard Institution, London, 2009.

[24] Mahmoud, A. H. "Effect of Alkalis and Sulfate on Portland Cement Systems", https://scholarcommons.usf.edu/cgi/viewconten t.cgi? referer=https://www.google.com/\&httpsre dir $=1 \&$ article $=3541 \&$ context $=e t d$, Accessed on May 13, 2017.

[25] Junsomboon, J and Jakmunee, J "Determination of Potassium, Sodium and Total Alkalies in Portland Cement, Fly Ash, Admixtures and Water of Concrete by a Simple Flow of Injection Flame Photometric System", Journal of Automated Methods and Management in Chemistry, Vol. 2011, pp 1-9.

[26] Smaoui, N., Berube, M. A., Fournier, B., Bissonnete, B. and Durand, B. "Effects of Alkali addition on the Mechanical Properties and Durability of Concrete", Cement and Concrete Research, Vol. 35, 2005, pp 203-212.

[27] Selman, M. M. and Ali, A. M. "The Effect of Alkali on the Properties of Portland Cement", Anbar
Journal for Engineering Sciences, https://www.iasj.net/iasj?func=fulltext\&aId $=69$ 050, Accessed on March 23, 2020.

[28] Mullick, A. K. "Performance of Concrete with Binary and Ternary Cement Blends", The Indian Concrete Journal, Vol. 81, Number 1, 2007, pp 15-22.

[29] Adinna, B. O., Nwaiwu, C. M. O. and Igwagu, C. J. "Effect of Rice Husk Ash Admixture on the Strength and Workability of Concrete", Nigerian Journal of Technology (NIJOTECH), Vol. 38, Number 1, 2019, pp 48-51.

[30] Ettu, L. O., Nwachukwu, K. C. and Arimawa, C. T. G. "Variation of Strength of OPC-sawdust Ash Cement Composites with Water-cement Ratio", International Research Journal of Engineering and Science (IRJES), Vol. 2, Number 7, 2013, pp 9-13.

[31] Kosmatka, S. H., Kerkhoff, B. and Panarese, W. C. Design and Control of Concrete Mixtures, $14^{\text {th }}$ edition, Portland Cement Association, Stokie, 2002.

[32] American Society for Testing and Materials. "Standard Test Methods for Consistency and Setting Times of Cement Paste", ASTM C150-15, Annual Book of ASTM Standards, ASTM International, West Conshohocken, PA, 2015.

[33] Neville, A. M. Properties of Concrete, $5^{\text {th }}$ Edition. Wiley, New York, 2011.

[34] Abiodun, Y. O. and Jimoh, A. A. "Microstructural Characterisation, Physical and Chemical Properties of Rice Husk Ash as Viable Pozzolan in Building Material: A Case Study of Some Nigerian Grown Rice Varieties", Nigerian Journal of Technology, Vol. 37, Number 1, 2018, pp 71-77.

[35] Mark, B., Gawu, S. K. Y., Adjaottor, A. A. and John, S. A. "Early and Late Strength Characterization of Portland Cement containing Calcined Low-grade Kaolin Clay", Journal of Engineering, Vol. 2016.

[36] Olutoge, F. A., Quadri, H. A. and Olafusi, O. S. "Investigation of the Strength Properties of Palm Kernel Shell Ash Concrete", ETASR-Engineering, Technology and Applied Science Research, Vol. 2, Number 6, 2012, pp 315-319.

[37] Babak, M. "Development of Concrete Water Absorption Testing for Quality Control" https://spectrum.library.concordia.ca/978086/1/ Full Text\%2C Master Thesis\%2C Babak Moha mmadi \%286200532\%29.pdf, Accessed on March 14, 2017. 